\title{
THE IMPLEMENTATION OF MIND MAPPING TECHNIQUE IN TEACHING WRITING: A CASE STUDY AT MAN 13 JAKARTA
}

\author{
Edy Waloyo \\ IAIN Syekh Nurjati Cirebon \\ edyibnuyahya@yahoo.co.id
}

\begin{abstract}
The objective of this study is to investigate the implementation of mind mapping in teaching writing narrative text. This study is conducted at the eleventh grade students of social class of Madrasah Aliyah Negeri 13 Jakarta. This study uses qualitative research design to find the answer of the objectives of the research. The data is collected by classroom observation, the teacher's and the students' interview, and students' works. All the data are collected, classified, and analyzed. The data which could represent to answer the objective of the research are taken as the example. The example data are used as proves of the research finding. The research finding of this study shows that mind mapping has good influences to the students writing skill. It equips the students with clear guideline to write because it allows students think freely and creatively. The students understand the text organization of narrative, the tense in writing narrative, and how to determine the sequence of the story based on the mapping and key words provided.

Key words: mind mapping, teaching writing, narrative text, qualitative
\end{abstract}

\section{BACKGROUND}

English is an important subject in this global era as it forces the education in Indonesia to prepare the students to master English. In order to face global era, Indonesia's government made rules that English subject has to be taught since junior high school. In fact, although students have been learning English since junior high school, most of them have problems to master English because there are four skills that must be learnt, such as; listening, speaking, reading, and writing. However, among these four skills, writing is the most difficult one to be learnt. It can be seen from the students' ability in writing paragraph still low although they have been learning writing from junior high school. The following are the example of the students' writing works at Islamic State Senior High School (MAN 13 Jakarta).

1. "I life in Pejaten timur. Pasar minggu. My hobby is singing and reading. I have three brother. He's life in Semarang" (M)

2. "I live in pasar minggu. I want to make my parent proud of me about. I have drem. My hoby doctor" (HM)

Based on the example above, there are some problems that students make in their writing when they are asked to tell about themselves. There are a lot of factors that influence the students' problems in composing a paragraph such as grammar, punctuation, limited vocabulary and limited time to practice. According to Oshima and Hogue (1999:3) states writing, particularly academic writing is not easy. It takes study and practice to develop this skill. It can be said that writers need a long time to engage with writing skill. They often meet difficulties in looking for the idea that they are going to develop into paragraph. In fact, the writers who have good writing, they have to work 
hard to do a lot of practices. In the beginning, they will meet some problems in writing their experimental drafts. In short, good writing is not easily to be accomplished because the most difficult step in writing is how the writer creates good opening in the first paragraph as it has important part to the whole text.

Therefore, people should know the writing process that will help them realize specific goals at each stage of composing progress. The process of writing must provide a series of planned learning exercises to help them understand the nature of writing at every point. In addition, Richards (1990: 100) states that learning to write is the most difficult tasks, a learner encounters and that few people can be said to fully master. A suitable approach which facilitating or guiding students in exploring students' thought or idea in writing text is needed in teaching and learning writing.

Related to the discussion above, it can be assumed that teaching writing is a hard duty because the teachers have to guide the students on constructing paragraph patiently. The teachers also have to facilitate the students with appropriate technique that can stimulate, motivate them in expressing their ideas. Furthermore, the teachers have to solve the students' problems that occur in process of writing. Gunawan (2002) states that teachers tend to teach students about word formation, vocabulary, grammar, theories of writing, and thus ignoring the practice of writing. As the result, students and college graduates do not know how to write. It also happens to the students of MAN 13 Jakarta in learning English Writing. In the writing session, they often say that they can do nothing. They are lack of vocabulary and ideas, and do not know how to write, and to create grammatical sentences. Besides, they sometime feel bored with the teacher's teaching method.

In order to overcome the problems that students face in writing class, some of the teachers at MAN 13 Jakarta often apply mind mapping technique in teaching narrative text. Mind mapping is technique that is used in the prewriting activity. It directs the students to write words which have relationship with the topic that they are going to discuss by using a lot of branches of words around the topic. It is also planning activity in the writing that is done by writing key words around the topic and then, it can be used to expand the students' ideas into good paragraphs.

In line with the statement above, Naqbi (2011) stated, "Mind mapping do help students to plan and organize their ideas for writing tasks." It can be assumed that mind mapping is one of the learning techniques that can facilitate students to improve their writing skill. Moreover, it can overcome the students' problems in generating their ideas in the writing class. In addition, it is expected to make the students feel confident to write good paragraphs.

In fact, mind mapping is relatively new technique in Indonesia that is expected to facilitate and guide students of MAN 13 Jakarta to explore their ideas by using note taking in a blank paper that will develop from words, sentences up to paragraphs. It is also expected to motivate students and make them confident to express their ideas through writing. Moreover, it can give the students chance to dig information and knowledge deeply about the topic. Dealing with this, in this study, the writer will analyze the implementation of mind mapping in teaching narrative text at MAN 13 Jakarta. The formulation of this study is how is the mind mapping implemented in the teaching writing narrative text? 


\section{Definition of Writing}

Oshima and Hogue (1999:3) state that writing is a process, not a product. It can be said that writing is process of gathering ideas through thinking which makes the readers get the points of the paragraph; the writer has to arrange the sentences smoothly. Writing also includes the process of review and rechecks the contents of the writing to get the best arrangement and to help the readers are easy to understand the content of the paragraph. Hedge (2002:302) mentioned that writing was the result of employing strategies to manage the composing process which was one of gradually developing a text. It is clear that in the writing activity needs serious attention and good strategies to create valuable text. The strategies which appropriate students' need will help them to organize their idea and guide their thought in the process of constructing paragraph.

On the other hand, Lindemann (1982:11) added that writing was defined as a process, communication, graphic system and convey a message. It means that writing is an activity of communication which uses a paper or other material to convey a message or information through graphic system. Furthermore, Petty and Jensen (1980: 362) stated that writing was a process of expressing thoughts and feelings, and of shaping experiences. It can be said that writing is an activity that needs full concentration to generate and compose ideas into sentences and paragraph through many steps that cannot express orally. By writing, the writers can share their feeling, knowledge and experiences with a great impression.

\section{Objectives of Writing}

Every activity run well when there is an objective on it. It is very important part in every activity in daily life because without having objective the activity does not organize well. In writing, an objective must be understood by the writers to make the process of writing on track. Students actually have an objective why they write something. Generally, every kind of writing has some objectives. White (1998) stated that the objectives of writing are to improve academic performance and enhance personal and community relationship. It can be said that writing gives the writers chance to manage and explore their skill and to create a good relationship with the others.

However, according to Harmer (2004:34), the objective of writing is "To help students to become better writers and to learn how to write in various genres using different registers." while, Richards (1990) states, "Writing is used either as evidence of successful learning or as a means of learning." It can be assumed that writing leads to a product that can be examined and reviewed immediately; it provides feedback to teacher and learner what has been understood.

Meanwhile, the objective of writing activity at school is as noted in the SchoolBased Curriculum- Kurikulim Tingkat Satuan Pendidikan (KTSP) for the eleventh grade students of senior high school is "Mengungkapkan makna dalam teks esei berbentuk report, narrative, dan analytical exposition dalam konteks kehidupan sehari-hari." (2008). It can be obviously seen that the main purpose of writing is to express or convey ideas to others and to influence the reader's decisions, actions, or beliefs. Furthermore, at school, the objectives of writing have to follow the guideline that stated on competence standard and basic competence.

\section{Mind Mapping}

Buzan (2005) stated that, mind mapping gives different types of learners the opportunity to excel and useful for gifted learners as they do not place limitation on 
their learning but allow the learners to develop creativity in limitless ways. Based on the statement above, it can be said that mind map gives learners freedom to explore everything from their mind and express it freely. Hedge (1988, p. 30) states that making a mind map is a strategy for note-making before writing; in other words, scribbling down ideas about a topic and developing those ideas as the mind makes associations. In line with Hedge, Hayes (1992:203) states that through mind mapping students turns random thoughts into patterns that can be written down and developed. Students become increasingly motivated to complete a writing task as their ideas emerge in organized forms. It can be stated that mind mapping facilitates the writers to explore their ideas or maximizes their brain to develop their writing skills. In order to make students eager to apply mind mapping, it offers some characteristic that make students interest and happy to apply it. Moreover, Steele (2012) stated "Mind map is a strategy for making notes on a topic, prior to writing. It is a structured strategy, which shows the (hierarchical) relationship of ideas." It can be said that mind mapping technique focuses in the pre writing which allows students to write down the ideas on the blank paper freely. It also offers flexibilities and interesting features to the students because they can use picture or color words to generate ideas. Furthermore, mind mapping technique can facilitate discussion among the students in order to collect information or words that they do not understand. The students will feel that write paragraph is enjoyable because mind mapping directs their writing by its key words.

Based on the discussion about mind mapping above, it is clear that mind mapping have many applications in every aspect of life, such as in personal, family, education, and business situation where improved learning and clearer thinking can enhance human performance. Mind map is a technique that helps the learner to think and remember better, solve the problems and take action. It also encourages creativity and flexibility, and help to think outside the box. So, mind mapping in writing text is expected can overcome the students' problems in mastering writing skill.

\section{Teaching Writing through Mind Mapping}

Teaching is a process of gaining information, knowledge, and skills through direct instruction. To gain information, knowledge, and skills, the teachers can use some appropriate techniques. At MAN 13 Jakarta, some of the teachers use mind mapping in teaching writing. Based on the objective of the teaching writing in first semester, the students are asked to create narrative, descriptive, and news items texts. However, this study analyzed the implementation of mind mapping technique in teaching writing narrative text because it made the writer more focus in doing research. In order to teach writing narrative text through mind mapping successfully, the teacher explained narrative text, text organization, mind mapping, how to draw mind mapping, and how to bring ideas in mind mapping into paragraph.

\section{Related Research Report}

In this part, the writer discussed the previous researchers who applied Mind mapping in teaching English. Nurhayati (2010) stated "The learners like and feel more confident using mind mapping in storytelling that facilitate or help them in speaking." It can be said that in the speaking class, mind mapping technique can improve the students' speaking skills. The students do not think that speaking class is hard subject because mind mapping help them to explore their ideas and experiences. Moreover, mind mapping technique also has good impact to the students' writing skills. As Aulia 
(2011) stated that mind mapping strategy was effective and successful to improve the students' ability in writing skills, particularly in terms of gathering ideas for the target topic, and to facilitate them in learning writing.

In addition, Naqbi (2011) said that mind mapping did help students to plan and organize their ideas for writing tasks under exam conditions. It meant that mind mapping provided key words which were used as a planning and could catch the writers' ideas about what they had to write in their writing. It can be said that Mind mapping is technique to facilitate students in enhancing their ideas. The students can do mind mapping before they start to write because it gives chance to the students to write their ideas into key points freely. After the students have written their ideas, they can arrange the ideas into the first paragraph up to the final result of writing. It means that mind mapping can be used as master plan of the whole paragraphs and the students just follow what they have taken down.

Based on the discussion above, this study focused on the analysis of the implementation of mind mapping technique in teaching writing particularly in teaching writing narrative text. It analyzed the whole teaching and learning process in the class to know how the teacher conducted mind mapping in teaching narrative text included with what the teacher's and the students' problems. Besides, this study analyzed the process of the study when the students drew mind mapping and developed their mind mapping into narrative text. Furthermore, it analyzed the teacher's and the students' responses to the usage mind mapping teaching and learning process.

The position of this study to support the previous research about the advantage mind mapping in writing. It focused on the process of teaching writing and writing process which used mind mapping technique. It explored the activities of the teacher and students when they bring mind mapping in the writing class.

\section{METHOD}

This study the writer used qualitaive research design because it attempted to investigate phenomenon of mind mapping in teaching and learning writing. Merriam (1988) stated that qualitative cases study was an intensive, holistic description and analysis of a single instance, phenomenon, or social unit. The writer physically attended the class to do observation and went to the teacher and students to conduct interview. It was done to collect valid data which used to answer to the research question.

The participants of the study were the eleventh grade students of XI IPS B class at MAN 13 Jakarta that consisted of 25 students and an English teacher who has been teaching them. The writer chose an English teacher and all the students as samples of the research. The writer took all students as sample because of the theory from Arikunto (2002: 112) who states that "if the subject is less than 100, it is better taken all so research study population. If the subject is greater may be taken between $10-15 \%$ or 20 $25 \%$." The data collected in multiple techniques of data collection methods. They were observation, interview and documents. The data included facts that was found in the observation, from an English teacher's and the students' interviews, and the documents. To get documents, the writer looked for and analyzed the documents which related with the research. To get the observation data, the writer observed the English teacher's and the students' classroom activities. To get the interview data, the writer prepared questions that answered by the English teacher and the students.

The writer did some activities like collecting information from the field, classifying the information into categories, formatting, and taking example. The 
writer also analyzed the data through coding. The observation data consisted of video recording and observation transcript. All the data from the observation used to analyze the teacher's effort in teaching writing through mind mapping. The observation data also used to analyze the teacher's problems in teaching writing narrative text through mind mapping.

In order to analyze the teacher's and the students' perceptions about mind mapping, the writer used the data from interview. The process of interview recorded to avoid the missing information from interviewee. After that the writers interpreted the recorded interview and analyzed all the information. To know the validity data from interview, the writer crossed check with the observation data.

In analyzing the documents, the writer analyzed the material which was taken from the teacher's documents like the lesson plan or RPP, and students' works. The students' work was used to analyze the students' problems in writing through mind mapping technique. Besides, the writer crossed check with the video record to get more information about the students' problems.

\section{FINDINGS and DISCUSSION}

This chapter focuses on describing the result of the implementation of mind mapping technique in teaching writing. According to the research questions, the result findings were divided into three parts. They consisted of the teacher's effort in applying mind mapping technique on teaching writing narrative text, the teacher's and the students' problems in teaching and learning narrative text through mind mapping, and the teacher's and the students' responses to the using of mind mapping technique.

\section{a. The process of teaching mind mapping}

In this process of explaining mind mapping technique, the teacher is a role model in the class because the success and the failure of this process depend on her effort in delivering the concept of mind mapping. The success of teaching mind mapping is influenced by the teacher's skill, knowledge, and experience about the usage of this technique. When the teacher has those aspects, the teacher can guide the students in mastering mind mapping easily.

\section{Example 1:}

Writer : How long have you been teaching English?

Teacher : I have been teaching English about ten years.

Writer : How do you teach writing to your students?

Teacher : I teach writing through clustering, and mind mapping.

Writer : What kind of teaching technique do you usually apply in teaching writing?

Teacher : I usually teach writing by mind mapping.

Writer : What is mind mapping?

Teacher : Mind mapping is a technique like a map to answer the question who, what, when, where, and why and it is actually peta konsep.

(Taken from the result of the teacher' interview)

The interview data above showed that the teacher's background was good. It meant that she had a lot of experiences in teaching writing, knew techniques in teaching writing, and understood the concept of mind mapping very well. The success of the students' writing depends on the teacher' effort in guiding the students starts from pre writing, process, ad up to the final work. Pre - writing is the important step that 
influences the process of writing, so the teacher must be creative in deciding the technique which is used in pre writing activity. The good experience of the teacher in teaching writing through mind mapping is expected help the students to write paragraph.

\section{Example 2:}

Teacher : Do you know mind mapping?

Students : Mind mapping.

Teacher : Ok, mind mapping is pemetaan or peta konsep. So, it is strategy to taking note before writing. Look at this! (The teacher is showing definition of mind mapping and giving example of creating mind mapping). In creating mind mapping you have to pay attention these procedures: first, put an idea or picture in the middle of paper. Second, create three main branches around the idea and write orientation, complications, and resolutions on or under the branches. Third, create some small branches in each main branch after. Fourth, draw picture or write key point of the story, you can write a word or two words and remember don't write a full sentence. The last, don't forget to create mind mapping colorfully because it will be more interesting.

Students : Can we draw pictures for the clues or key point?

Teacher : Yes, of course. But you may use single word or two words. Ok, any question about mind mapping?

Students : No, miss.

(Taken from the result of classroom observation)

The process of delivering concept of mind mapping ran smoothly. It can be seen from the teacher's effort in providing good material and media. The teacher showed the definition of mind mapping by using power point which made the students interested to active in the process of study. As the result, the students understood about definition of mind mapping and how to draw mind mapping because the teacher gave some examples of how to draw mind mapping. Furthermore, the students were interested in drawing mind mapping because they could draw some pictures or key point which made them were not bored.

\section{b. The process of drawing mind mapping}

In this process, the teacher accompanied the students in drawing mind mapping which they would develop into narrative text. The teacher not only gave clear instruction how to draw mind mapping but also she guided the students always on the track. It meant that in process of drawing mind mapping, the teacher reminded the students to follow the procedures of drawing mind mapping and to pay attention to the language features of narrative text.

\section{Example 3:}

Teacher : Do you have any questions? (In the process of drawing mind mapping)

Student1 : Yes. Could I combine picture and word in drawing mind mapping miss?

Teacher : Okay, you can do both of them.

Student2 : How about coloring, Miss?

Teacher : You can use a pencil and after you have finished you can add color to your work. 
(Taken from the result of classroom observation)

The example 3 showed that the students were not sure with their work. It meant that they were still doubt to decide key words which they would use in drawing mind mapping. The key words in mind mapping were important things that would influence to the students' narrative text. So, the teacher helped the students to do something that make them enjoy in the class such as; using pencil, and coloring in drawing mind mapping. Moreover, the key words in the students' mind mapping were guidance for their writing that helped them to write the narrative text based on the text organization and language features. On the other hand, the teacher duty was to facilitate and help the students when they got problems in drawing mind mapping. The teacher did her duty very well because she always helped and gave solution when their students found problems.

\section{c. The process of developing mind mapping into narrative text}

The important role of the teacher in this process is a fully needed. It means that the teacher has to set or manages the class in good situation in order to make the students feel comfortable in the process of writing text. Besides, the teacher has to prepare suitable example of writing narrative text through mind mapping technique. The process of giving example in writing narrative text through mind mapping can be seen below.

\section{Example 4:}

Teacher : Let's try to write narrative from the example of mind mapping. (The teacher is showing mind mapping about Cinderella) We can start from topic. The title is Cinderella. Then continue with orientation. Once upon the time, Complete this orientation!

Student1 : There was lived a girl named Cinderella.

Teacher : Ok continue this orientation!

Student2 : Cinderella has two step sisters. They are lazy and bossy.

Teacher : Please check your friend writing. Is it true?

Students : No, miss.

Teacher : Yes, the verb must be verb 2. It must be "Cinderella had two step sisters. They were lazy and bossy". Next sentence.....

Student3 : She had a step mother who fierce and very cruel.

Teacher : There is miss word or to be past. It must be "She had a step mother who was fierce and cruel." We continue to the next part. It is complication. One day.......please continues!

(Taken from the result of classroom observation)

The data above showed that the teacher knew well her role in the class. It can be seen that she did not ask the students to write narrative text directly after she had explained about narrative text and mind mapping. The teacher guided the students patiently to transferred mind mapping into narrative text. Moreover, the teacher did not gave the example of transferring mind mapping in narrative text directly but she opened discussion by giving clue or key point on the white board that would be continued by the students. The teacher's stimulus was good because the students were interested to continue the teacher's clue by writing the sentences on the white board. After one of the students had continued the teacher's clue, the teacher asked the other students to read or check their friend sentences and the grammar. When the students found the mistakes on their friend writing they told it to the teacher and she would give feed back to the 
students and always reminded her students to be careful to follow the language features on narrative text.

\section{Practice 1:}

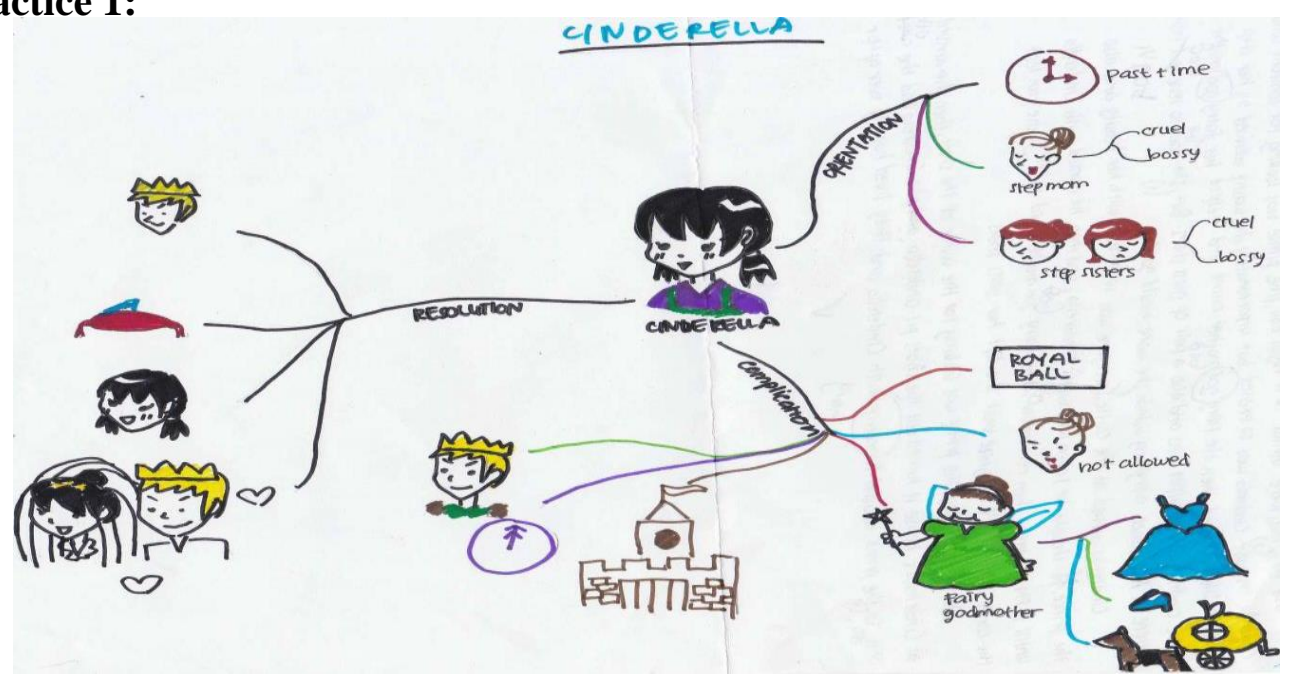

Figure 4.2 Example of Mind Mapping Practice 1

(Taken from student work)

The finding are relevant with the theory propose by Buzan (2006:15). He stated that drawing mind map was started from central idea, use picture or photograph, make colorful main branches, add curve line and write key word in each branch and curve line. It can be said that the students able to draw mind map and serve some information about story of Cinderella.

\section{CIINDERELLA}

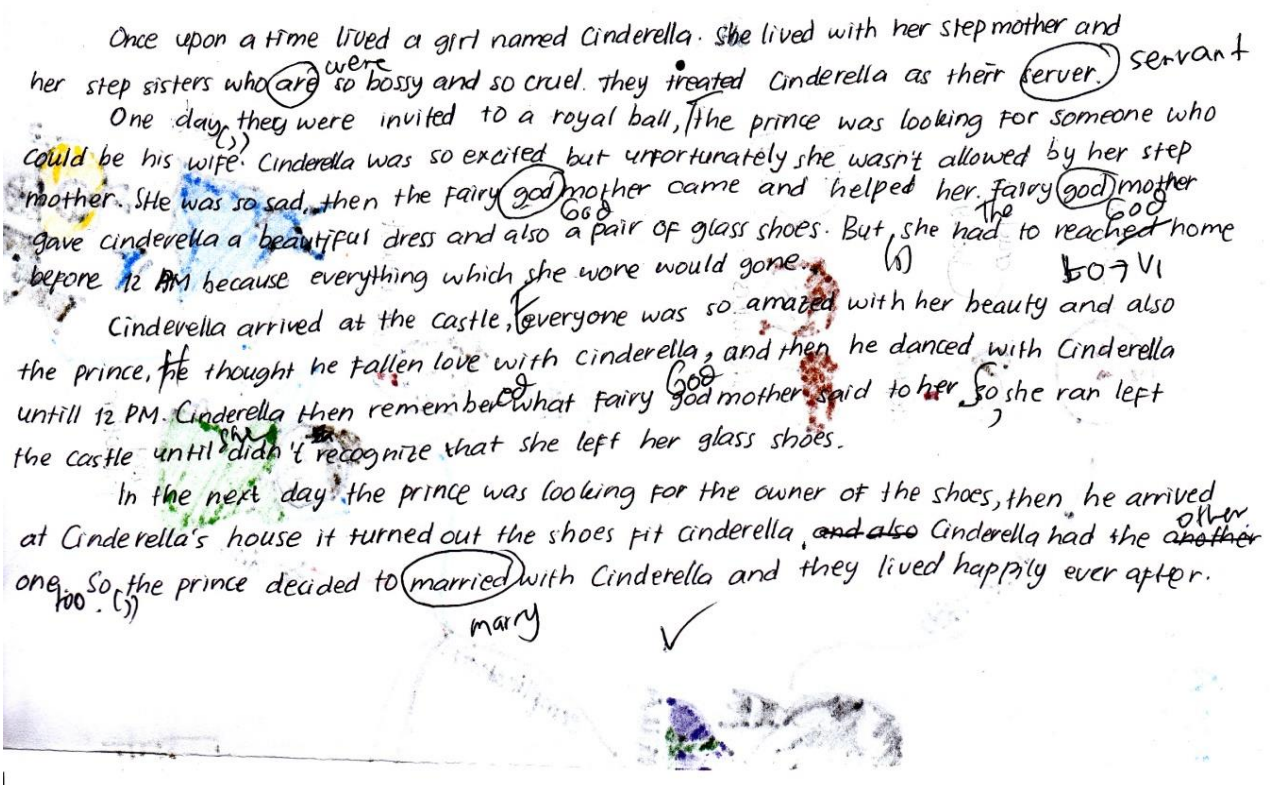

Figure 4.3 Example of student' writing practice 1

(Taken from student work) 
The example of the students' work above showed that mind mapping had good influence to the result of their writing. It can be seen clearly from the first up to the last paragraph; the student knew the text organization of narrative text, used past tense in writing the text, and knew the sequences of the story. Besides, mind mapping had important role to help students in exploring their knowledge about the story, so it stimulated students' brain to recall their memory which had relation with the whole story.

Moreover, in the process writing narrative text, the students did not need to think about plot of the story deeply because they were facilitated by mind mapping that provided the sequences of the story. There were guidelines which could be fostered by the students in writing narrative text. It could be assumed that mind mapping helped the students to think creatively because they had drawn their plan and in the process of writing just added the complete story.

\section{DISCUSSION}

\section{The process of teaching writing narrative text through mind mapping technique}

Teaching writing is not quite easy since some teachers do not really expose their students to write the diary, story, or even paper. It can be seen in the final exam when the students are provided by the multiple choice questions. The test does not assess the students' writing skill. As a result, they are not used to write the text. However, the standard competence of KTSP curriculum for XI grade shows the writing must be taught since it is a part of the curriculum.

Narrative text is one text that is learned by the students of eleventh grade. It is a text which provides some stories like fable, folk story, myth, legend, or fairy tales. The text is more popular than the other text because the students will feel entertained after reading the text. The problem may arise when the students are not exposed to write narrative text. They may be know how to read narrative text, but they do not know how to write it. Thus, the teacher must take a charge in encouraging and teaching them how to write narrative text. For example, the teacher can use mind mapping technique to help the students in learning writing.

The research found that the process of teaching narrative text through mind mapping ran smoothly. It can be seen as follows; first, the result of teaching concept of narrative text showed that the teacher did her duty very good. She used power point to make the students interested to follow the discussion. As the result, the students know what narrative text is because they still remember it from the previous semester. Second, the result of explaining mind mapping showed that it was new for the students so the teacher had to explain many times. Third, the result of drawing mind mapping showed that in the beginning the students got difficult to draw and wrote the key words but after the teacher explained many times, the students could draw mind mapping creatively and effectively. The finding above is in line with Buzan (2006:4) who stated that mind map was effective and creative take note, and naturally mapped our thought.

In the last process is developing mind mapping into narrative text. The result shows that mind mapping really helps the students in writing narrative text. It is relevant with the assumption of mind map in writing stated by Buzan (2006:184). He states that mind map not only help in planning of writing but also useful when writing the full text. Mind map guide the students how to determine the sequence of the story based on the mapping and key words provided. Mind mapping also equip students with clear guideline in constructing narrative text. Moreover, mind mapping helped the students to 
decide the suitable tense in their writing. That is why this technique is useful for the early beginning level in writing particulary for those who do not really know how to write narrative text.

\section{CONCLUSIONS AND RECOMMENDATIONS}

In summary, teaching writing through mind mapping technique shows that the students do not directly understand to draw mind mapping but after several process of doing the mind mapping, the students are guided to write narrative text through mind mapping. Through the mind mapping, the students are bale to comprehend the text organization of narrative, the tense, and the sequences of the story in general. It is clear that teaching writing is not easy duty, it needs creative person to organize the class through various approaches, methods and techniques which suitable with students' need and able to overcome the problems of teaching and learning process.

\section{REFERENCES}

Aulia, V. 2011. Using Mind Mapping to Improve the Fourth Semester Students' Writing Skills of Example Essays in the English Department of FKIP Unisma. Unpublished Thesis. Malang: State University of Malang. http://karyailmiah.um.ac.id/index.php/disertasi/article/view/17067. Retrieved April $2^{\text {nd }}$, 2012

Arykunto, Suharsimi. 2013. Prosedur Penelitian Suatu Pendekatan Praktik. PT RinekaCipta: Jakarta.

Buzan, T. 2005. The Ultimate Book of Mind Maps. London: Harper Collins publisher Ltd.

Buzan, T. 2006. Buku Pintar Mind Map. Jakarta: PT Gramedia Pustaka Utama

Departemen Pendidikan Nasional. 2003. Kurikulum 2004 : Standar Kompetensi Mata Pelajaran Bahasa Inggris Sekolah Menengah Atas dan Madrasah Aliyah.

Gunawan, I.D. 2002. Collaborative Writing in EFL Clasroom: A Qualitative study at English Department of Pasundan University Bandung. Unpublished Master Thesis. UPI Bandung. P.1

Harmer, J. 2004. How to Teach Writing. Edinburg Gate. Longman.

Hayes, David A. (1992). A Sourcebook of Interactive Methods for Teaching with Text. United States of America.

Hedge, T. 2002. Teaching Learning in Language Classroom. New York: Oxford University Press.

Hedge, T. (1988). Writing: Resource Books for Teachers. Oxford University Press.

Lindemann, E. 1982. A Rhetoric for Writing Teachers. Oxford University press.

Merriam, S. B. 1988. Qualitative Research and Case Study Applications in Education. San Francisco: Jossey Bass.

Naqbi, S. A. 2011. "The Use of Mind Mapping to Develop Writing Skills in UAE Schools", Education, Business and Society: Contemporary Middle Eastern Issues, Vol. 4 Iss: 2, 
Nurhayati. 2010. Using Mind Mapping in Story Telling for English Competence improvement. Unpublished Thesis. Jakarta: University of Muhammadiyah Prof. DR. Hamka.

Oshima, A. and Hogue, A. 1999. Writing Academic Writing: Third Edition. Addison Wesley Longman.

Petty, W. T. and Jensen, J.M.. 1980. Developing Children's Language. Boston: Allyn and Bacon, Inc.

Richards, J. C. 1990. "From Meaning into Word: Writing in a Second or Foreign Language." The Language Teaching Matrix. Cambridge University Press.

Richards, J. C. 1990. The Language Teaching Matrix. New York. Cambridge: University Press.

Steele, V. Using Mind Maps to Develop Writing. http://www.teachingenglish.org.uk/ articles/using-mind-maps-develop-writing. Retrieved March 17 ${ }^{\text {th }}, 2012$. 